\title{
Exploring Leave Management Practices and Relationship with Performance of Administrative Staff: Evidence from a Tertiary Institution in Ghana
}

\author{
Mary Safowah Akom ${ }^{1, *}$, Charles Obeng-Sarpong ${ }^{2}$, Florence Enyonam Aflakpui ${ }^{3}$, Smart A. Sarpong ${ }^{4}$ \\ ${ }^{1}$ General Administration, Registry, Kumasi Technical University, Ghana \\ ${ }^{2}$ Public Relations, Registry, Kumasi Technical University, Ghana \\ ${ }^{3}$ Human Resource, Registry, Kumasi Technical University, Ghana \\ ${ }^{4}$ Centre for Social Science Research - CSSR, Kumasi Technical University, Ghana
}

Received March 14, 2021; Revised April 19, 2021; Accepted May 23, 2021

\section{Cite This Paper in the following Citation Styles}

(a): [1] Mary Safowah Akom, Charles Obeng-Sarpong, Florence Enyonam Aflakpui, Smart A. Sarpong , "Exploring Leave Management Practices and Relationship with Performance of Administrative Staff: Evidence from a Tertiary Institution in Ghana," Universal Journal of Management, Vol. 9, No. 3, pp. 71 - 82, 2021. DOI: 10.13189/ujm.2021.090301.

(b): Mary Safowah Akom, Charles Obeng-Sarpong, Florence Enyonam Aflakpui, Smart A. Sarpong (2021). Exploring Leave Management Practices and Relationship with Performance of Administrative Staff: Evidence from a Tertiary Institution in Ghana. Universal Journal of Management, 9(3), 71 - 82. DOI: 10.13189/ujm.2021.090301.

Copyright $\odot 2021$ by authors, all rights reserved. Authors agree that this article remains permanently open access under the terms of the Creative Commons Attribution License 4.0 International License

\begin{abstract}
Effective leave management encompasses integrated processes that involve employees, supervisors and human resource managers. This study explored leave management practices and relationship with the performance of University administrators, using a Technical University as a case study. This became necessary due to the systemic challenges associated with the current leave management practices. The purpose of this research was to solicit the views of staff on the leave management practices and how it affects performance. Using Yamane (1967) sample determination formula, a total of 96 University administrators were conveniently selected from a population of 200 to participate in the study A self-administered questionnaire was adopted as the primary instrument for data collection. The analysis of the results focused on the cause-effect relationship between leave management and staff performance using regression. The hypothesis that there is no linear relationship between the predictor and dependent variable was rejected. The study, therefore, concludes that there exists a linear relationship between the predictor (Leave system) and the dependent variable (Staff performance). The study further established that the leave application process at the University is more manual than electronic and also bureaucratic. It is also unevenly distributed over the year
\end{abstract}

but rather heavily tilted towards the last two quarters of the year where majority of staff (86\%) take their annual leave. It is, therefore, recommended that management institutes measures to enhance the efficiencies in the leave management practices by automating the processes to reduce bureaucracies, errors, and also ensure yearly even distribution of the leave.

Keywords Leave Management, Technical Universities, University Administrators, Non-teaching Staff

\section{Introduction}

Education underpins any human and social development. A well developed and equitable system of Higher Education (HE) that promotes comprehensive learning by amalgamating the necessary resources to improve learning is crucial for the development of any emerging knowledge economy [1]. Again, [2,3] acknowledge that education is a critical mover of growth and advancement.

In view of the fact that the skills needed to build a knowledge economy are mostly acquired at the tertiary 
level, countries must pay attention to improving their $\mathrm{HE}$ systems. It behoves on Ghanaian HE institutions and policy makers to ensure that their human resource is equipped with the requisite skills to compete, innovate, and respond to the multifaceted social, environmental, and economic conditions around them $[4,5]$. In spite of the many challenges' institutions face in the business world, they must be ready to respond to the dynamic and competitive business environment by meeting all stakeholder expectations, including the needs of personnel.

The success of any organization is broadly dependent on its human resources. In recent years, organizations have focused greatly on human resource management practices particularly due to the upsurge in strategic human resource management approaches $[6,7,8]$. An establishment such as a technical university may fail in gaining a high level of efficiency in its personnel management function without a well-functioning Human Resource Department. Human Resource Management activities such as HR planning, recruitment and selection, performance and compensation management, employee engagement as well as leave management leave are vital for the success of the organization. Leave management practices, though not very much hyped, take a considerable time of HR staff work and also affect the performance of the organization.

HR staff must seek to balance compliance of leave policies with maintaining adequate staff at all times to ensure continuous work while ensuring that employee satisfaction is retained. Leave management practices have a significant impact on the organization. This is basically because employees paid time off have substantial bearing on productivity and the finances of the organization $[9,10$, 11]. In order for the organization to thrive, a reliable leave management system is needed. Poor leave management practices could have a negative effect on employee performance. It may further affect employee morale and consequently affect mission deliverables.

Effective leave management practices are an integrated system which encompasses employees, managers as well as HR practitioners $[12,13]$. Both internal and external control measures must be instituted to maintain efficient leave management processes in public higher educational institutions. Internal control measures, including compliance with leave management processes must be applied for managing leave. Sharma [14] acknowledged the strategic importance of leave and adduced five (5) vital concerns directly linked to leave management. These comprise meeting mission delivery deadlines; legal issues regarding leave; the emotional aspects linked to leave issues; the financial consequence; as well as performance issues. Leave, as an integrated procedure, is guided using an array of legislative as well as policy frameworks [14].

Leave management has assumed an important strategic duty for institutions to guarantee that employees use the assigned leave period suitably, and avoid accumulating leaves. In an attempt to carry out the HR functions, [14] specifies that leave management consumes a substantial amount of management's time. Managers are in charge of managing institutional plans by making sure that required resources are available to implement leave management functions while at the same time ensuring that personnel are carrying out their assigned jobs.

Employees working in Technical Universities in Ghana comprise both teaching staff and non-teaching staff. This distinction separates the core teaching staff from service providers who render support services to ensure that teaching and learning occur smoothly. The non-teaching staff include administrative, professional and technical staff who are in charge of assisting, supporting and guiding authorities to effectively manage and run these institutions to fulfil the universities mandate.

Currently, the approval of leave for the administrative staff does not conform to established policies. Again, the practice does not ensure that adequate human resources are available for the daily smooth running of the University. The majority of the administrative staff proceed on leave in the second half of the year; most especially within the last three months of the year. This puts the remaining staff under enormous pressure to deliver on the University's mandate and thereby slows down performance. Hence, the non-existence of regular and effective monitoring and evaluation of the leave management system lead to shortage of human resources at certain times of the year. The current leave management system is not automated but carried out manually, leading to bureaucracies and errors.

The purpose of the study is to establish the relationship between leave management and the performance of University administrators. The study also explores the current leave management processes in the University; determines whether the University has an efficient structured method of recording, managing, monitoring and measuring leave management practices for stimulating institutional effectiveness; identifies the challenges of the leave management practices and suggests recommendations.

Above all, this study shall test the Hypothesis that; Leave management practices have no statistically significant impact on the performance of administrative staff of a University.

\section{Literature Review}

\subsection{Administrators in Technical Universities in Ghana}

Technical universities by their mandate provide educational services to students to support the development of human resources of the nation as a whole. These services comprise teaching, research, academic support, industrial liaison and career development, counselling, accommodation and residence services and among others to meet the needs of the increasing and diverse student 
body. Thus, staff in the technical universities in Ghana comprise both teaching and non-teaching staff.

The use of non-teaching staff or administrative staff in educational institutions has increased significantly in recent years, and there has been much discussion of their role and tasks $[15,16]$. Universities mostly aim at optimizing the process of adjustment to university life for students by offering them information, resources, aid and education. Consequently, professionals working in universities usually include administrative personnel to help fulfil the University's objectives [17, 18].

Specifically, the administrative units of technical universities are in charge of general human resources management activities; academic affairs, general administration; public relations and protocol services, financial affairs management; procurement; ICT; archives; scientific and technological services; and any other process of administrative management necessary to support and fulfil the objectives of the university.

Universities have their enabling instruments from the law creating them and it is that instrument, which indicates the mandate, sets out the governance structure, and identifies the principal/key officers. Technical universities have integrated administrative set ups that work together in harmony to achieve the institutions' overall aim. In order to have a smooth and effective technical university administration for the achievement of its mandate, systems and policies must be put in place to guide its activities some of which are controlled, directed and coordinated including leave management.

\section{Leave Management}

Leave management is the process involved in the requisitioning, granting or denying staff time off from work taken into consideration the effects on the institution and also ensure that records on same are kept $[19,20]$. This may include managing leave related to annual leave, personal or family member sickness, childbirth, and any other event that could give rise to the absence of the employee. Leave entitlements are usually in accordance with one's rank or seniority, job classification, or directed by labour regulations of the country [21, 22, 23]. Some employers may offer paid leave to staff as a way of gaining personal leave days.

At any given time, it is essential to appreciate the availability of resources in an organization. It guarantees that work continues efficiently and uninterrupted. Thus, the leave management process directly correlates with the performance and/or productivity of an organization. Leave is a form of staff benefit and it is a crucial human resource management tool available to employers to guarantee a healthy and productive work environment [19, 24]. The principal aim of leave is to give workers the opportunity to rest so as to ensure that they maintain high levels of productivity $[9,11]$.

Organizations sometimes underrate the effect employee absence from work can have on productivity. As inferred by [25] and [26], the average cost of staff absenteeism is estimated at $36 \%$ of employees' salary, while absenteeism may give rise to $19 \%$ daily net lost in productivity. The indirect cost of employee absenteeism includes the interruption of work, overtime payments, engagement of temporary or casual workers, stakeholder's dissatisfaction, as well as employee turnover [27, 10, 28]. Most organizations do not have the tools to track accurate reports on leave and assume that staff take a few days' sick days annually $[29,30]$. However, once they conduct even a manual report, they are stunned by the outcomes. Leave is, therefore, viewed as a strategic tool that has financial value. This is so because leave entitlements are taken with pay.

\subsection{Types of Leave}

There are various types of leave as enshrined in the conditions of service of an organization and the labour laws of a country. In Ghana, the Labour Act 2003 (Act 651) [33] grants some basic leave entitlements to workers. All these defined leave entitlements have explicit leave days associated with them. Leave management is pertinent in the public as well as the private sector to ensure the availability of required human resources for running the organization. Therefore, employers and employees should agree on leave schedules that ensure uninterrupted work while also ensuring that it is flexible to meet the social and family obligations of staff. There are several categories of leave, including annual leave; maternity leave; sick leave; sabbatical leave; casual leave, family responsibility leave; special leave etc.

\section{Annual leave}

Annual leave denotes a stated minimum number of days that organizations give employees paid days away from work yearly [31, 32]. Section 20 of Ghana's Labour Act 2003, (Act 651) [33] indicates that every worker in any organization is entitled to a minimum of 15 working days leave with full pay for every year of continuous service. The taking of annual leave is mostly contingent on the supervisor and HR department agreeing to the date for an employee's annual leave. According to [34], a worker qualifies for annual leave after being in employment for a continuous period of a year either on permanent or part-time basis. Annual Leave entitlements are mostly recurrent or cyclical and may occasionally of necessity be accumulated. Annual leave is calculated yearly, based on the date the worker was employed [29, 26, 35].

\section{Sick leave}

The [33] of Ghana; Section 24 describes sick leave as a period an employee is allowed to be absent from work due to sickness. Sick leave must be certified by a qualified medical practitioner and it shall not be counted as part of annual leave. All employees in an organization are entitled 
to sick leave. Sick leave is calculated in calendar days and is not carried on to a subsequent year. The maximum duration for sick leave may differ from one organization to the other. However, generally in the public sector in Ghana, sick leave may be granted up to a maximum one year. Sick leave has multiple factors connoting that there are varied health reasons leading the employee to seek permission for sick leave $[20,22,36]$. Sick leave may be for a short period, temporary or permanent incapacitation arising out of occupational injuries and other diseases. In all cases, the policy of the organization on sick leave and the labour laws shall apply.

Employees are required to inform their immediate superior about their absence from work as a result of sick leave $[37,22]$. Staff are expected to use sick leave for medical appointments, hospitalization, etc. Permanent incapacitation leave of absence may be granted to any employee who is unable to continue his/her day-to-day task as may be certified by a qualified medical practitioner. A worker is thus qualified for occupational injuries and disease leave if he/she contracts any illness from the workplace.

\section{Maternity leave}

As part of compulsory employee benefits, most labour laws protect expectant and nursing mothers from unsafe work for herself and the child [38]. According to [39], female employees qualify for a period of four (4) months maternity leave. However, in Ghana, Section 57 (1) of [33] provides for at least twelve (12) weeks maternity leave for female workers upon the production of a medical certificate issued by a certified medical officer which indicates the expected date of confinement. Thus, female employees may take the maternity leave before their due date as decided by a medical practitioner. The maternity leave is in addition to any period of annual leave the female worker is entitled. The Act further provides for the payment of full remuneration of female workers on maternity leave in addition to any other benefit she is entitled to. It further debars an employer from dismissing a woman worker who absents herself from work on grounds of maternity leave.

\section{Family responsibility leave}

Some labour laws provide for family responsibility leave. This type of leave may also be referred to as compassionate leave. This category of leave is approved for employees whose spouses die or give birth [40, 41, 38]. It may also be granted when an employee's immediate family member dies. A stated number of days usually ranging from three to five days may be assigned to such leave. This kind of leave terminates at the end of the year.

\section{Casual leave}

Casual leave can be applied for by an employee when he/she is unable to be present in the office as a result of situations of an emergency nature. It is calculated in working days. Most public Universities in Ghana may grant a maximum of ten (10) days casual leave in a year. Such leave may be given by the employer after the annual leave has been exhausted. It cannot be carried over into the subsequent year. The institution has the right to disallow any casual leave it is not satisfied with the reasons provided for the absence of the employee for which the casual leave is being requested for [40].

\section{Sabbatical leave}

Sabbatical leave is a leave of absence granted for the purpose of study, research, or other pursuits of value to boost the scholarly agenda of an organization. Universities in Ghana grant up to a maximum of two years' sabbatical leave depending on the number of years an employee would have worked with the institution.

\section{Special leaves}

Additionally, other types of special leave such as study leave, examination leave, and resettlement leave may be granted to employees especially in public institutions.

\subsection{Vital Components of Leave Management}

Business activities in an organization are realized through established standards, policies and procedures. Furthermore, the achievement of institutional success is through ingenious strategic direction, objectives, strategies, as well as effective implementation and communication strategies [11]. As inferred by [42] and [43] institutions achieve their strategic direction through their strategic plan, vision and mission's statements as well as their value statements. A strategic direction is employed to define goals for the workers and is usually linked with the mission statement of the organization. Ordinarily, institutions HR policies are developed to support the organizational goals. HR activities are vital in realizing institutional goals and thereby sustain corporate continuity.

The leave policy is intended to control the various forms of leave benefits that accrue to staff and are due them and to put in place processes and procedures that will be used in the granting and taking of such leaves [40, 22]. The objectives of leave management in most public institutions are to put in place arrangements that would guarantee the setting up of appropriate measures in the management of leave in the workplace to meet planned and unplanned staff leave requirements such as resulting from personal/family issues, and temporary or permanent incapacitation.

To ensure effective leave management therefore, it is necessary to deploy appropriate technology for automating the leave processes; implement and communicate leave policy; and regularly monitor and evaluate the policy. Automating the leave management system will make the leave processes efficient, simple to handle, reliable and also make readily available data on leave. As leave 
management is digitalized, the probability for error and loss of data is reduced and workload less as maximum work is done by automated software [44].

Regarding implementation and communication of plan, the activities required for executing the policies must be defined. Implementation strategies thus, define the tasks and/or activities that will occur; employees responsible for them; the resources required such as human and financial and the timeframes. Regular monitoring and evaluation of the leave is required through the generation of reports to ascertain the effectiveness of leave management processes. These would guarantee that human resources are soundly managed, efficiently and competently utilized [42].

\subsection{Significance of Leave Management}

Granting employees leave is important to maintain a healthy work-life balance. Leave forms part of mandatory staff benefits which are backed by labour laws. These benefits are expected to be managed in a proper way to guarantee that employees do not lose their leave entitlements, and employers also do not lose financially. When employees are denied leave, it may lead to low levels of employee engagement which could lead to a massive loss in productivity $[45,46]$.

Since leave is a cyclic process, satisfactory control, as well as active monitoring is necessary in order to realize effectiveness and efficiency. As personnel take time away from work, some duties must be performed. There is therefore the need for institutions to balance staff leave requirements while ensuring an uninterrupted workflow. Thus, managers must ensure that leaves are well planned, approved and well documented.

The management of leave can be complex. Thus, it is essential to have an efficient leave management process. An efficient process could easily predict the levels of employee engagement and satisfaction at the workplace. The management and administration of leave should take into consideration an effective leave roster and as much as possible, eliminate unscheduled leave. Inconsistencies that ensue in the process of leave administration must be eliminated as such discrepancies could prevent the organization from operating at its optimal level. Poorly managed leave processes could have financial and legal ramifications for the organization.

\section{Methods}

The study used a correlational survey design and also sought to describe the situation as it pertains. According to [47] and [48], apart from fact findings, descriptive studies may sometimes result in the formulation of essential principles of knowledge and solution to obvious challenges and may comprise measurement, classification, analysis, comparison and interpretation of data.

Again, a quantitative approach was adopted, which involved the gathering and analysis of numerical data. This approach may be used to identify patterns and averages, make predictions, test causal relationships and generalize results, to a broader population [49, 50]. A self-administered questionnaire was adopted as the primary instrument for data collection. To ensure cross-sectional representation, respondents were selected from various categories of staff from selected administrative departments of the University. Regression analysis was done to test the cause-effect relationship between leave management and staff performance using ANOVA.

A mathematical approach by Yamane (1967) was adopted in deriving the sample size for the study. For a $95 \%$ confidence interval and with a population of about 200, the sample size was obtained with the formula below.

$$
\mathrm{n}=\mathrm{N} /\left(1+\mathrm{Ne}^{2}\right)
$$

$\mathrm{n}=$ sample size for employees

$\mathrm{N}=$ Population for respondents

$\mathrm{e}=$ level of precision (5\% margin of error) (5\% margin of error)

$$
\text { Sample size }=\frac{200}{\left(1+200 * .05^{2}\right)}=133.33 \approx 130
$$

Using the sample size determined administrators from across the ten (10) administrative departments/units were randomly selected to participate in the study. From the predetermined sample size, a total of 130 questionnaires were conveniently distributed to administrative staff; however, only 96 questionnaires were retrieved and used for the analysis.

\section{Findings}

\subsection{Demographic Profile of Administrators}

A summary of the general characteristics of the University administrators surveyed is presented in Table 1. The results showed the University administration to be dominated by females $59 \%$. The mean age range of the administrators who participated in the study was between $36-40$ years, with the majority having worked with the University between $6-10$ years. Most of the administrative staff at the time of the study was master's degree holders in various academic disciplines. The majority of the administrators were drawn from the Registrar's office and the Finance Directorate (72.9\%). Furthermore, almost two-thirds (72.9\%) of the administrators were Senior Members of the institution. 
Table 1. Demographic Profiling of Respondents

\begin{tabular}{|c|c|c|}
\hline Gender & Frequency & Percent \\
\hline Female & 57 & 59.4 \\
\hline Male & 39 & 40.6 \\
\hline Total & 96 & 100.0 \\
\hline \multicolumn{3}{|l|}{ Age (years) } \\
\hline $18-30$ & 2 & 2.1 \\
\hline $31-35$ & 25 & 26.0 \\
\hline $36-40$ & 28 & 29.2 \\
\hline $41-45$ & 17 & 17.7 \\
\hline$>45$ & 24 & 25.0 \\
\hline Total & 96 & 100.0 \\
\hline \multicolumn{3}{|l|}{ Educational Qualification } \\
\hline Diploma (HND) & 5 & 5.2 \\
\hline Bachelor's degree & 12 & 12.5 \\
\hline Master's degree & 74 & 77.1 \\
\hline $\mathrm{PhD}$ & 3 & 3.1 \\
\hline Others & 2 & 2.1 \\
\hline Total & 96 & 100.0 \\
\hline \multicolumn{3}{|c|}{ Working Experience (years) } \\
\hline $6-10$ & 37 & 38.5 \\
\hline $11-15$ & 31 & 32.3 \\
\hline$>15$ & 28 & 29.2 \\
\hline Total & 96 & 100.0 \\
\hline \multicolumn{3}{|l|}{ Department } \\
\hline Finance Directorate & 10 & 10.4 \\
\hline Procurement office & 4 & 4.2 \\
\hline Registrar's office & 60 & 62.5 \\
\hline Internal Audit & 6 & 6.2 \\
\hline ICT Directorate & 2 & 2.1 \\
\hline Planning \& Quality & 3 & 3.1 \\
\hline Other & 11 & 11.5 \\
\hline Total & 96 & 100.0 \\
\hline \multicolumn{3}{|l|}{ Category of staff } \\
\hline Senior Member & 70 & 72.9 \\
\hline Senior staff & 26 & 27.1 \\
\hline Total & 96 & 100.0 \\
\hline
\end{tabular}

More than two-thirds $(n=82,85.4 \%)$ of the respondents were aware of the leave processes as it is implemented in the institution. More so, when asked concerning their knowledge of the leave days' administrators qualify for each year; an overwhelming majority $(n=92,95.8 \%)$ of the respondents responded in the affirmative that for a particular year they know the number of leave days they are entitled to. However, concerning the possession of the policy document on leave administration in the University, two-thirds $(n=72,75 \%)$ of the administrators indicated they do not have copies of the document for their personal references on issues concerning leave management in the institution (See Table 2). The results imply that the administrators are aware and have knowledge about the leave processes implemented in the institution. However, they do not possess copies of policy documents on the leave process in the institution.

Table 2. Knowledge about leave System at the University

\begin{tabular}{|c|c|c|c|}
\hline Variables & Yes & No & $\begin{array}{l}\text { Not } \\
\text { sure }\end{array}$ \\
\hline $\begin{array}{l}\text { Awareness of leave processes } \\
\text { implemented in this institution }\end{array}$ & $\begin{array}{c}82 \\
(85.4 \%)\end{array}$ & $\begin{array}{c}10 \\
(10.4 \%)\end{array}$ & $\begin{array}{c}4 \\
(4.2 \%)\end{array}$ \\
\hline $\begin{array}{l}\text { Knowledge about the leave } \\
\text { days administrators qualify for } \\
\text { each year }\end{array}$ & $\begin{array}{c}92 \\
(95.8 \%)\end{array}$ & $4(4.2 \%)$ & \\
\hline $\begin{array}{l}\text { Administrators possess copies } \\
\text { of policy document on leave } \\
\text { process in the institution }\end{array}$ & $\begin{array}{c}18 \\
(18.8 \%)\end{array}$ & $72(75.0)$ & $\begin{array}{c}6 \\
(6.2 \%)\end{array}$ \\
\hline
\end{tabular}

\subsection{Leave Management Practices}

This section deals with the perceptions held by the administrators regarding their experiences on the leave management processes implemented in the University. Table 3 shows the University leave management system is planned $(n=70,72.9 \%)$ as the majority of the respondents agreed to that effect. That notwithstanding, close to two-thirds of the respondents perceive the leave management processes to be more manual with 70 , representing $72.9 \%$ of the respondents responding Yes. In contrast, the majority of the respondents $(n=60,62.5 \%)$ maintained that the system is not electronic.

Table 3. Leave Management Process

\begin{tabular}{lccc}
\hline Variables & Yes & No & Not sure \\
\hline The university has a planned leave management system & $70(72.9 \%)$ & $10(10.4 \%)$ & $16(16.7 \%)$ \\
The leave application process is manually done & $70(72.9 \%)$ & $14(14.6 \%)$ & $12(12.5 \%)$ \\
The leave application process is done electronically & $22(22.9 \%)$ & $60(62.5 \%)$ & $14(14.6 \%)$ \\
There are bureaucracies in the leave application process & $40(41.7 \%)$ & $36(37.5 \%)$ & $20(20.8 \%)$ \\
There are self-service portals for applying for various leaves & $4(4.2 \%)$ & $76(79.2 \%)$ & $16(16.7 \%)$ \\
Copies of leave application forms are returned to HODs & $(80(83.3 \%)$ & $6(6.2 \%)$ & $10(10.4 \%)$ \\
All administrators are informed of their leave credits regularly & $22(22.9 \%)$ & $42(43.8 \%)$ & $32(33.3 \%)$ \\
All administrators are encouraged to take their leave accrued in a year & $54(56.2 \%)$ & $24(25.0 \%)$ & $18(18.8 \%)$ \\
\hline
\end{tabular}


However, from the results in Table 3, it could be observed that opinions were sharply divided among the administrators concerning the levels of bureaucracy in the leave management system at the University. The majority $(n=40,41.7 \%)$ noted that there are bureaucracies in the application process. Additionally, there are no self-service portals relative to the application of various leave by members of the University administration as more than two-thirds ( $\mathrm{n}=76,79.2 \%)$ objected to the assertion. Again, a summary of the responses further showed that the majority $(n=80,83 \%)$ of the respondents agreed that returning copies of the leave application forms to the respective Heads of Department remains a standard practice at the University.

Also, approximately half $(\mathrm{n}=54,56 \%)$ of the respondents agreed that all administrators are encouraged to take their leave accrued in a year. However, 42 representing about $44 \%$ of the respondents indicated that they are not informed of their leave credits regularly. It is worth noting that a significant number $(n=32,33 \%)$ of the respondents were not sure if administrators are informed of their leave credits. The results point out that the University has instituted a planned leave management system to manage leave schedules for its members. Besides, all administrators are encouraged to take their leave accrued in the year. However, the results demonstrate that the leave application system was more manual than electronic and bureaucratic as well. Similarly, the University lacks a self-service portal to support the application process. The administrators are not informed of their leave credits regularly.

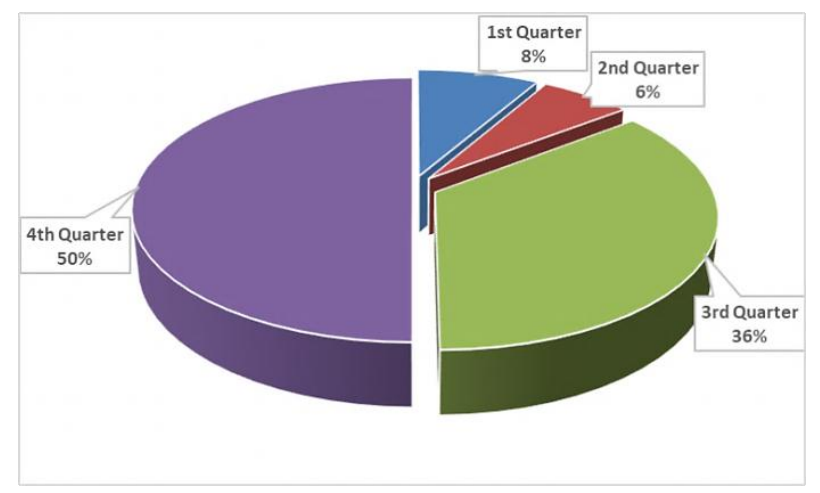

Figure 1. Time of the year administrators normally proceed on leave

Exactly half $(50 \%)$ of the respondents prefer to go on leave in the fourth quarter of the year that is a time-spanning between October to December of each year. Additionally, $36 \%$ of the respondents pointed out that they prefer to take their leave during the $3^{\text {rd }}$ quarter of the year. It can be inferred that the administrative staff on the average prefers to take their leave during the last 6 months of the year.

\subsection{Evaluating the Leave Management System}

Table 4. Evaluation of Leave System

\begin{tabular}{lccccc}
\hline Variables & $\mathbf{N}$ & Min. & Max. & Mean & $\mathbf{\pm S D}$ \\
\hline $\begin{array}{l}\text { There are systems instituted to } \\
\text { monitor leave non-compliance }\end{array}$ & 96 & 1 & 4 & 2.31 & .987 \\
$\begin{array}{l}\text { Leave reports are taken from the } \\
\text { general administrative system }\end{array}$ & 96 & 1 & 4 & 2.73 & 1.041 \\
$\begin{array}{l}\text { Audits are regularly conducted } \\
\text { on leave administration }\end{array}$ & 96 & 1 & 4 & 1.75 & .906 \\
\hline
\end{tabular}

Scale: Very large extent $=5$, large extent $=4$, moderate extent $=3$, small extent $=2$, not at all $=1$

The respondents were asked to evaluate the leave system in the institution. When asked about the availability of a system to monitor leave non-compliance, the majority of the respondents $(\mathrm{M}=2.73, \pm \mathrm{SD}=.987)$ indicated that to a small extent the University has a system in place to monitor leave non-compliance. The results further show that the majority of the respondents also observed that, to a small extent, leave reports are drawn from the general administration system $(\mathrm{M}=2.31, \pm \mathrm{SD}=.987)$. However, most of the respondents $(\mathrm{M}=1.75, \pm \mathrm{SD}=.906)$ believe that audits are not conducted regularly on the administration of leave at the University. The results in Table IV indicate that to a relatively small extent, the University has a system instituted to monitor leave non-compliance and that leave reports are taken from the general administration system. The study further discovered that the leave management process is not regularly audited.

Table 5 sought to assess the opinions of respondents on the effects of leave management on their performance at work. Most of the administrators indicated that to a moderate extent, the leave system as implemented in the institution can predict the levels of employee engagement $(\mathrm{M}=3.02, \pm \mathrm{SD}=.906)$; most of the respondents perceive that to a moderate extent the leave system in the institution improves their performance $(\mathrm{M}=3.25, \pm \mathrm{SD}=1.016)$; while reducing their stress and burnout from overworking $(\mathrm{M}=3.54, \pm \mathrm{SD}=1.142)$; and also reduces the staff truancy tendencies $(\mathrm{M}=3.10, \pm \mathrm{SD}=1.090)$. Additionally, the respondents indicated that to a small extent there is high employee turnover due in part to the leave system in the institution $(\mathrm{M}=2.15, \pm \mathrm{SD}=1.105)$; encourages more sick days to be taken $(\mathrm{M}=2.38, \pm \mathrm{SD}=1.039)$; does relatively small extent motivate staff to put in more efforts $(\mathrm{M}=2.31$, $\pm \mathrm{SD}=1.199$ ). 
Table 5. Leave management and staff performance

\begin{tabular}{|c|c|c|c|c|c|}
\hline Variables & $\mathbf{N}$ & Min & Max & Mean & \pm SD \\
\hline It can predict the levels of employee engagement & 96 & 1 & 5 & 3.02 & .906 \\
\hline The leave system in the institution improves my performance & 96 & 1 & 5 & 3.25 & 1.016 \\
\hline Our leave system reduces my stress and burnout from overworking & 96 & 1 & 5 & 3.54 & 1.142 \\
\hline Our leave system reduces high staff absenteeism tendencies & 96 & 1 & 5 & 3.10 & 1.090 \\
\hline There is high employee turnover due in part to the leave system in the institution & 96 & 1 & 4 & 2.15 & 1.105 \\
\hline More sick days are taken due to the leave system & 96 & 1 & 5 & 2.38 & 1.039 \\
\hline The leave system in the institution does not motivate staff to put in more efforts & 96 & 1 & 5 & 2.31 & 1.199 \\
\hline
\end{tabular}

Scale: Very large extent $=5$, large extent $=4$, moderate extent $=3$, small extent $=2$, not at all $=1$

Table 6. Reliability of indicators

\begin{tabular}{lc}
\hline \multicolumn{1}{c}{ Item } & Cronbach's Alpha \\
\hline Staff Performance & \\
It can predict the levels of employee engagement & 0.877 \\
The leave system in the institution improves my performance \\
Our leave system reduces my stress and burnout from overworking \\
Our leave system reduces high staff absenteeism tendencies \\
There is high employee turnover due in part to the leave system in the institution \\
More sick days are taken due to the leave system \\
The leave system in the institution does not motivate staff to put in more efforts \\
\hline Leave System \\
There are systems instituted to monitor leave non-compliance \\
Leave reports are taken from the general administrative system \\
Audits are regularly conducted on leave administration
\end{tabular}

Table 7. Impact of leave management on performance

\begin{tabular}{|c|c|c|c|c|c|c|}
\hline Source & SS & df & MS & & Number of obs. & 96 \\
\hline Model & 1.329 & 1 & 1.329 & & $\mathrm{~F}(1,98)$ & 6.687 \\
\hline Residual & 32.997 & 94 & .201 & & Prob $>F$ & 0.025 \\
\hline \multirow[t]{3}{*}{ Total } & 34.327 & 95 & 1.530 & & $\mathrm{R}$ & .397 \\
\hline & & & & & R-squared & 0.157 \\
\hline & & & & & Adj. R-squared & 0.048 \\
\hline Emp_Perf & Coef. & Std. Err. & $\mathrm{t}$ & $\mathrm{P}>|\mathrm{t}|$ & & \\
\hline Leave & -.383 & .353 & 9.908 & .000 & & \\
\hline _cons & 3.498 & .197 & -4.946 & .039 & & \\
\hline
\end{tabular}

The University leave system, as implemented, moderately predicts employee engagement, affects employee performance, reduces stress and burnout, and also reduces staff absenteeism. That notwithstanding, the study found that to a small extent, the leave management processes implemented at the University lead to high employee turnover, more sick days and also demotivate staff to put in more effort. [27], [10], [28] works corroborate the findings which were noted that disruption, overtime, temporary workers, stakeholder's dissatisfaction as well as employee turnover could all be considered as excesses associated with the leave management.

\subsection{Reliability Analysis}

The internal consistency of construct was accessed to establish their reliability. From table 6, all two constructs had a good internal consistency ranging from 0.877 for Staff performance to 0.936 for Leave System.

\subsection{Impact of Leave Management Practices on the Performance of Administrative Staff}

This section sought to statistically assess leave management practices as implemented at the University and how it impacts the performance of administrative staff. 
It focuses on the cause-effect relationship between leave management and staff performance using regression. The ANOVA in table 7, presents results from the test of the null hypothesis that R-square is zero. An R-square of zero indicates no linear relationship between the predictor and dependent variable. The computed $F$ statistic was found to be 6.687, with an observed significance level $p<0.025$. Thus, the hypothesis that there is no linear relationship between the predictor and dependent variable is rejected. We therefore conclude that there exists a linear relationship between the predictor (Leave system) and the dependent variable (Staff performance). The impact of leave systems on Staff performance gave us a correlation coefficient of 0.397. This means that there exists a direct moderate relationship between Staff performance and the Leave systems implemented in the University. Still from Table 7, the analysis gave us an R-square value of 0.157 . This means that leave system explains up to 15.7 percent of the total variability in the performance of staff of the University. An examination of coefficients shows leave system significantly impacts negatively, the degree of staff performance at the University.

\section{Discussion}

The study sought to investigate the correlation between leave management practices on employee performance. It hypothesized that Leave management practices have no statistically significant impact on the performance of administrative staff at the University. The hypothesis that there is no linear relationship between the predictor and dependent variable was rejected. The study therefore concludes that there exists a linear relationship between the predictor (Leave system) and the dependent variable (Staff performance). [52] endorses that employee job performance is enhanced in organizations that offer 'supplemental family leave policies.

The study confirms that the administrators are aware and have knowledge regarding the leave processes implemented in the institution. However, they do not have access to copies of the policy document on leave administration. Furthermore, it was discovered that the University had established a planned leave management system to manage leave schedules for members of the institution. The study also observed that the administrative staff have access to copies of leave application forms, and copies are also returned to the Heads of Department. It was found that the administrators are also encouraged to take their leave accrued in the year.

The study has proven that the leave Management process is mainly manual, hence making the process bureaucratic. The University does not have a self-service portal to support the leave application process. The manual processing of application forms creates inefficiencies and errors that lead to bureaucracies, thereby delaying the process. [53], indicates that an automated leave management will be useful for the institution to maintain the leave records of staff and reduce formalities and delays.

The study additionally revealed that most of the administrative staff prefer to proceed on leave during the last six (6) months, that is, the third and fourth quarters of the year. This implies that skeletal staff are available during this period of the year which thereby put them under excessive pressure to deliver on the University's mandated.

Evidence from the study suggests that to a small extent, the University has a system in place to monitor leave non-compliance but does not regularly audit the leave management process at the University. The leave management processes must be regularly audited to ensure compliance with the policy.

\section{Implication to Research and Practice}

The study is relevant in several ways to achieve effectiveness and efficiency in leave management for the benefit of both staff and the institution. The study contributes to the literature by establishing a relationship between leave management practices and staff performance in the University. From the analysis, there exists a direct moderate relationship between staff performance and the Leave systems implemented in the University.

The unavailability of self-service portals to facilitate leave management processes is a disincentive to both the institution and staff. The deployment of an automated leave manager system will provide timely records on leave to supervisors, the HR department and assist them in the scheduling of leave and thereby eliminate the bureaucracies associated with the current system. Staff will also have the opportunity to quickly view their leave balance and request leave accordingly. The introduction of such a system would enhance the efficiency of managing leave schedules in the institution. Management's efforts should focus on introducing strategies that will make the leave management process more effective and efficient.

As much as practicable, allowing majority of the workers to proceed on leave at a particular time of the year, especially during peak periods, should be avoided. When majority of staff go on leave at a specific period, it puts the remaining staff under enormous pressure which may affect their health and thereby lead to the request for more sick leave. This eventually slows down productivity. Management should therefore institute measures to ensure that the leave roaster is evenly distributed in a year and does not significantly affect performance or slows down productivity. Management must adopt strategies to ensure that the leave management system motivates staff to give off their best while significantly reducing the negative effects such as increase number of sick days taken by employees. 


\section{Conclusions}

Leave management practices have implications for staff perfomance. The practice has a linar relationship with performance. Employers need to pay more attention to the bottlenecks associated with the administration of leave. One of the obvious ways to enhance the leave management prsctices is to invest in automation. That way, it reduces bureaucracies, errors and speeds up the processing of staff leave. Again, a well structured leave roster that evenly distributes staff leave over the twelve months of the year will be useful to ensure that the work of the institution runs smoothly throughout the year and also avoid work overload on the remaining staff.

\section{Future Research}

Obviously, the leave management has cost implications for the organisation. Future research may consider the cost implications of leave management practices to the organistion.

\section{REFERENCES}

[1] Karpov A., Kharin A., Kharina O., "Educational environment forming on the basis of the human capital development." SHS Web of Conferences, Vol. 29, no. 02919, EDP Sciences 2016. DOI://doi.org/10.1051/shsconf/201629 02019

[2] Donou-Adonsou, F., "Technology, education, and economic growth in Sub-Saharan Africa." Telecommunications policy, vol. 43, no. 4, pp. 353-360, 2019.

[3] Adu D. T., Denkyirah E. K., "Education and economic growth: a co-integration approach." International Journal of Education Economics and Development.Vol.8 No. 4, pp.228-249, 2017.

[4] Hanushek E. A., "Education production functions. The economics of education, Academic Press pp. 161-170, 2020.

[5] Omodero C. O., Nwangwa K. C., "Higher Education and Economic Growth of Nigeria: Evidence from Co-Integration and Granger Causality Examination.” International Journal of Higher Education. Vol. 9, No. 3, pp. 173-182, 2020.

[6] Elrehail H., Harazneh I., Abuhjeeleh M., Alzghoul A., Alnajdawi S., Ibrahim H. M., "Employee satisfaction, human resource management practices and competitive advantage: the case of northern cyprus." European Journal of Management and Business Economics, 2019.

[7] Moore L. F., Jennings P. D., "Human resource management on the Pacific Rim: Institutions, practices, and attitudes". Vol. 60, Walter de Gruyter GmbH \& Co KG, 2017.
[8] Delery J., Gupta N., "Human resource management practices and organizational effectiveness: internal fit matters." Journal of Organizational Effectiveness, People and Performance, 2016.

[9] Afsana H., "Employee leave management system in MetLife Bangladesh" 2018.

[10] Trusic A., Fosic I., Starcevic D. P., "Invisible Financial Costs of Employee Absenteeism." Economic and Social Development: Book of Proceedings, PP.817-826, 2017.

[11] Moleki M.T., "Leave management for promoting organizational efficiency in the Department of Correctional Services and the Department of Home Affairs." Pretoria region (Doctoral dissertation, North West University).

[12] Ahammad T., "Personnel management to human resource management (HRM): How HRM functions." Journal of Modern Accounting and Auditing Vol. 13, No. 9, pp. 412-420, 2017.

[13] Reddy V., Prinsloo C. H, Netshitangani T., Moletsane R., Juan A., Janse van Rensburg D., "An investigation into educator leave in the South African ordinary public schooling system" 2010.

[14] Sharma S. K., "Handbook of HRM practices: Management policies and practices." Global India Publications; 2009.

[15] Molina O. A., "Visionary Leadership in the Administrative Staff of the Guapan Educational Unit." Journal of Technology and Science Education, Vol.8, No. 2, pp. 115-125, 2018.

[16] Balyer A., Ozcan K., Yildiz A., "Teacher empowerment: School administrators' roles." Eurasian Journal of Educational Research, vol.17, No. 70, pp. 1-18, 2017.

[17] Udegbunam E. O., Ogoegbunam U. O., Attamah E. C., "Administrative Staff Perception of Human Resources Utilization in Tertiary Institutions in South-South Nigeria." International Journal of Recent Innovations in Academic Research. Vol. 4, no. 7, pp 48-59, 2020.

[18] Shishakly R., Sharma A., Gheyathaldin L., "Investigating the effect of learning management system transition on administrative staff performance using task-technology fit approach." Management Science Letters, vol. 11, no. 3 pp. 711-718, 2021.

[19] Bourdeau S., Ollier-Malaterre A., Houlfort N., "Not all work-life policies are created equal: Career consequences of using enabling versus enclosing work-life policies". Academy of Management Review. Vol. 44, no. 1, pp, 172-193, 2019.

[20] Kim J.S., Ryu S., "Employee satisfaction with work - life balance policies and organizational commitment: A Philippine study." Public Administration and Development, vol. 37, no, 4, pp260-276, 2017.

[21] Emeagwal L, Ogbonmwan K. O., "Mapping the perceived role of strategic human resource management practices in sustainable competitive advantage." Academy of Strategic Management Journal, vol. 17, no. 2, pp. 1-19, 2018. 
[22] Gatimu J. W., Kagiri A. W., "Influence of leave policy on employee satisfaction in telecommunication industry in kenya.” Journal of Human Resource and Leadership. Vol. 2 no. 7 pp. 41-57, 2017.

[23] Rubel M. R., Rimi N. N., Yusliza M. Y., Kee D. M., "High commitment human resource management practices and employee service behaviour: Trust in management as mediator." IIMB Management Review. Vol. 30, no 4, pp. $316-329,2018$.

[24] Amin M., Ismail W. K., Rasid S. Z., Selemani RD., “The impact of human resource management practices on performance.” The TQM Journal, 2014.

[25] Kocak M. C., Bryan T. G., Stevie Lynch M. B., "Effects of absenteeism on company productivity, efficiency, and profitability." Business and Economic Research, vol. 8, no. 1, pp. 115-135, 2018.

[26] Zhang W., Sun H., Woodcock S., Anis A. H., "Valuing productivity loss due to absenteeism: firm-level evidence from a Canadian linked employer-employee survey." Health economics review, vol. 7, no. 1, pp. 1-14, 2017.

[27] Memon M. A., Salleh R., Mirza M. Z., Cheah J. H., Ting H., Ahmad M. S., Tariq A., "Satisfaction matters: the relationships between HRM practices, work engagement and turnover intention." International Journal of Manpower, 2020 .

[28] Pirzada D. S., Hayat F., Ikram A. A., Ayub M., Waheed K., "Impact of human resources management practices on turnover, productivity and corporate financial performance." European Journal of Business and Management, vol. 5, no. 10, 163-176, 2013.

[29] Deery S., Walsh J., Zatzick C. D., Hayes A. F., Exploring the relationship between compressed work hours satisfaction and absenteeism in front-line service work." European Journal of Work and Organizational Psychology, vol. 26, no. 1, pp. 42-52, 2017.

[30] Wang J., Reid F., "The impact of work hours discrepancy on employee absence." International Journal of Manpower, 2015.

[31] Nisar S., and Siddiqui D. A., "A Survey on the Role of Fringe Benefits in Employee Satisfaction-An Analysis of Organizations of Pakistan." Business Management and Strategy, vol. 9, no. 1, pp. 232-252, 2019.

[32] Oludayo O. A., Falola H. O., Obianuju A., Demilade F., "Work-life balance initiative as a predictor of employees' behavioural outcomes." Academy of Strategic Management Journal, vol. 17 no. 1, pp. :1-17, 2018.

[33] The Ghana Labour Act 2003, Act 651, Sections 20-32 \&57

[34] Allen T. D., Lapierre L. M., Spector P. E., Poelmans S.A., O'driscoll M., Sanchez J. I., Cooper C. L., Walvoord A. G., Antoniou A. S., Brough P., Geurts S. "The link between national paid leave policy and work-family conflict among married working parents." Applied Psychology, vol. 63, no. 1, pp. 5-28, 2014

[35] Duff A. J, Podolsky M., Biron M., Chan C. C., "The interactive effect of team and manager absence on employee absence: A multilevel field study." Journal of Occupational and Organizational Psychology, vol. 88, no. 1, pp. 61-79, 2015 .
[36] Stapelfeldt C. M., Nielsen C. V., Andersen N. T., Krane L., Borg V., Fleten N., Jensen C. "Sick leave patterns as predictors of disability pension or long-term sick leave: a 6.75-year follow-up study in municipal eldercare workers." BMJ open, vol. 4, no. 2, 2014.

[37] Scognamiglio A., "Paid sick leave and employee absences." Labour, vol. 34, no. 3, pp. 305-322, 2020.

[38] Rossin-Slater M., "Maternity and family leave policy." National Bureau of Economic Research, 2017.

[39] Gelin C., "An Analysis on Maternity Leave Policies." Doctoral dissertation, California State University, Northridge, 2020.

[40] Moss P., Deven F., "Leave policies in Europe: current policies, future directions." International Journal of Sociology and Social Policy, 2019

[41] Bana S., Bedard K., Rossin-Slater M., "Trends and disparities in leave use under California's paid family leave programme: New evidence from administrative data." AEA Papers and Proceedings vol. 108, pp. 388-391, 2018.

[42] Wahjono S. I., Marina A., Rasulong I., Fen F. S., "Leave Management Information System using Inside DPS Software for the Efficiency of Human Resources Management." Kinetik: Game Technology, Information System, Computer Network, Computing, Electronics, and Control. pp. 211-218.

[43] Adamu A., "Employee Leave Management System.” Fudma Journal of Sciences, vol. 4, no.2, pp. 86-91.

[44] Haumshini R., Sathia Dev., T M., Mahendran R., "Digitalized Hostel Leave Management System" International Journal of emerging technology and innovative engineering, vol. 6, no. 01, pp.12-16, 2020).

[45] Shaukat H., Ashraf N., Ghafoor S., "Impact of human resource management practices on employees' performance.' Middle-East Journal of Scientific Research, vol. 23, no. 2, pp. 329-338, 2015.

[46] Beauregard T. A., Henry L. C., "Making the link between work-life balance practices and organizational performance." "Human resource management review." Vol. 19, no, 1, pp. 9-22, 2009

[47] Gray D. E., "Doing research in the business world" Sage, 2019.

[48] Rahi S., "Research design and methods: A systematic review of research paradigms, sampling issues and instruments development." International Journal of Economics \& Management Sciences, vol. 6, no. 2, pp. 1-5, 2017.

[49] Cooksey R. W., "Illustrating statistical procedures: Finding meaning in quantitative data." Springer Nature, pp.23-31, 2020 .

[50] Zyphur M. J., Pierides D. C., "Statistics and probability have always been value-laden: An historical ontology of quantitative research methods." Journal of Business Ethics, vol. 27, 1-18, 2019.

[51] Yamane T., Elementary sampling theory, 1967.

[52] Begall K., van Breeschoten L., van der Lippe T., Poortman A. R., "Supplemental family leave provision and employee 
performance: Disentangling availability and use." The International Journal of Human Resource Management, vol. 28, pp. 1-24, 2020.
[53] Malomo L., "Leave management system." International Journal of Multi-Disciplinary Research, (ISSN: 3471-7102, ISBN: 978-9982-70-318-5), 2018. 